\title{
Globalization: A Brief Primer for Counselors
}

By: Daniel M. Paredes, Kyoung Mi Choi, Maria Dipal, Arline R. A. C. Edwards-Joseph, Nikolai Ermakov, Ana T. Gouveia, Sachin Jain, Chieko Koyama, J. Scott Hinkle, James M. Benshoff

Paredes, D. M., Choi, K. M., Dipal, M., Edwards-Joseph, A. R., Ermakov, N., Gouveia, A. T., Jain, S., Koyama, C., Hinkle, J. S., \& Benshoff, J. M. (2008). Globalization: A brief primer for counselors in the United States. International Journal for the Advancement of Counseling, 30(3), 155-166.

The final publication is available at Springer via http://dx.doi.org/10.1007/s10447-0089053-1.

\author{
****C Springer. Reprinted with permission. No further reproduction is authorized without \\ written permission from Springer. This version of the document is not the version of \\ record. Figures and/or pictures may be missing from this format of the document. ***
}

\begin{abstract}
:
The concept of globalization elicits a wide range of reactions among the public, policy makers, and academics (Bennhold 2007; Bradsher 2006; Cheng 2005; Dobbs 2004; Friedman 2005; Gilbert 2006; Oppenheimer 2005; Stiglitz 2006; Winestock 2001; World Commission on the Social Dimension of Globalization 2004). Increased understanding of globalization can help counselors recognize their influential role as one of the few groups of professionals that operate in schools, mental health, and career counseling settings. Because the consequences of globalization impact every aspect of life, counselors have a responsibility to understand globalization systemically, including how it impacts the practice of counseling and how to help their clients function effectively in the context of globalization. In this article, which is intended as a primer for continued dialogue, globalization is introduced as an issue to be further studied and responded to by professional organizations around the world. Examples of globalization are offered and a case is made for continued collaboration between quality assurance and membership organizations in addressing globalization.
\end{abstract}

Keywords: Globalization | Counseling | International counseling | International guidance

\section{Article:}

\section{Introduction}

Globalization has been defined as the integration of economies through the exchange of goods, capital, people (labor), and knowledge (technology) (International Monetary Fund [IMF] 2002). Similar definitions emphasizing the trade of goods or services have been suggested by other authors (e.g., Coe et al. 2002; Collier and Dollar 2002; Conley 2002; Economic Commission for Latin America and Caribbean [ECLAC] 2002; Martin 2001; Organization for Economic Cooperation and Development [OECD] 2005; Lenn and Reason 2000). Generally speaking, the authors of these definitions have conceptualized globalization from an economics perspective, 
considering the cultural and personal-level aspects and consequences of globalization to be beyond their purview (OECD 2005; Stiglitz 2006).

By contrast, professional counselors routinely help their clients deal with the cultural and personal-level consequences that are directly or indirectly related to globalization (e.g., helping a child who is enrolling at a new school due to a parent's job relocation, job search or college enrollment following a downsizing). Counselors are, by definition, the intermediaries between systems (educational, healthcare, employment) and individuals (American Counseling Association [ACA] 2005; Federacion de Asociaciones Venezolanas de Orientadores [FAVO] 2001; International Association for Educational and Vocational Guidance [IAEVG] 1995; Singapore Association for Counselling [SAC] 2004). Despite increased attention to the development of counseling and counseling psychology internationally (Arredondo 2006; Clawson et al. 2002; Leong and Ponterotto 2003; Rollins 2006; Schweiger 2005), globalization has not directly been addressed in the counseling literature. A search on the PsycInfo database and the respective web pages of the world's long established international counseling organizations, the IAEVG and the International Association for Counselling, yielded no position statements from either organization on the topic of globalization. As a result, many counselors may not understand the processes, consequences, and opportunities that accompany globalization and the profession may be ill prepared to continue exploring the topic. Counselors may not be aware of why it is critical that counseling organizations take active steps to be involved in discussions of globalization and its consequences. As an example of what organizations might do, the US-based National Board for Certified Counselors (NBCC), Council for the Accreditation of Counseling and Related Educational Programs (CACREP), ACA, and Association for Counselor Education and Supervision (ACES) are establishing international presences so that they are better equipped to respond to globalization's consequences.

This article will provide a brief primer to help counselors understand what globalization is and how it is relevant to their work. Several examples of how the economics-based definition of globalization is manifested in everyday counseling practice are provided. The purpose of this paper is to help counselors better understand how their work in schools, mental health, and career counseling settings puts them in highly influential positions to help clients thrive in a globalized world. It is hoped that this paper may serve as a catalyst for dialogue regarding globalization by counselors worldwide as there is a critical gap in the counseling literature regarding the social/personal consequences of globalization and how counseling may respond institutionally. Understanding globalization will help counselors achieve the fundamental objective of empowering their clients to negotiate the demands of international challenges, understanding, and harmony.

\section{Defining Globalization}

Although the process of globalization has a legacy of several millennia, recent international events have highlighted its presence in the minds of many. Moreover, technology has played a key role in increasing our global interdependence, as the internet, cell phones, and other technologies have changed how we communicate and share information. In recent years, there have been many ongoing discussions about the migration of individuals, the rapid international spread of disease, multi-national military interventions, and the relocation of jobs to 
geographically distant places. Concerns about these changes and many others related to globalization have been recognized not only for their effects on economics and trade, but also for their influence on career/vocational, educational, and health systems (Batalova and Lowell 2006; Burawoy et al. 2000; Collins-Dogrul 2006; Sampson et al. 2000; Stead and Harrington 2000; Suarez-Orozco 2001; World Commission on the Social Dimension of Globalization 2004; World Health Organization [WHO] 2001). Counselors often work at the confluence of these systems to assist clients in identifying, choosing, and accessing resources available to help them function effectively.

\title{
Globalization in Media
}

Globalization has gained attention in the popular media because of the relocation of jobs to offshore sites or contractors, and because of anti-globalization protests around the world reported by traditional news outlets (Bradsher 2006; British Broadcasting Corporation 1999; Cheng 2005; Winestock 2001). Various commentaries about globalization are made by pundits and politicians alike (e.g., Bennhold 2007; Frist 2003; Kennedy 2006; Oppenheimer 2005). As evidenced by ongoing images of angry protestors in developed and developing nations, discussions of globalization can elicit strong responses. These commentaries and events, however, rarely provide an explanation of globalization that transcends a particular political agenda.

Globalization is a complex topic with multi-layered relationships that has proven to be difficult to define concretely and distinctly from political agendas (Friedman 2005; Radipati 2006; Stiglitz 2006). Nonetheless, in the midst of the economic and social fluidity that result from globalization, counselors are tasked with continuing to provide educational and career related services (both in school and employment counseling settings) and with attending to the mental health needs of individuals and families in crisis. Globalization is a topic that counselors around the world cannot afford to ignore. Counselors must have an understanding of the processes underlying globalization so that they can rise above the rhetoric in the popular media, help clients process their experiences relating to changes initiated by globalization processes, and help clients make informed choices in a globalized world.

\section{Current Definitions}

The most widely used definitions of globalization, provided by economists, provide a useful framework for counselors to understand globalization. By integrating definitions provided by economists (e.g., Collier and Dollar 2002; IMF 2002; OECD 2005), globalization can be defined as the integration of economies through the exchange of goods and services, capital, people (labor), and knowledge (technology). Although Polachek et al. (2005) suggested that the exchange of investment monies (capital) promotes peace and cooperation between nations by providing the potential for lost investment as a disincentive to engaging in hostilities, the exchange of capital is less directly related to counseling practice than the exchange of goods and services, labor, and technology.

\section{Globalization Issues and Counseling Practice Examples}

\author{
Exchange of Goods and Services
}


Globalization may be too narrowly defined in terms of trade in tangible items, such as cars, clothes, electronics, and other wares. In economic terms, the exchange of services also comprises a significant sector of the world economy and world trade. Nearly $80 \%$ of the US economy is accounted for by the service sector according to Vastine (2002). As one kind of service, education is promoted actively by many colleges and universities in the world market (Evelyn 2005; Institute of International Education 2005; Massey University 2008; McMurtie 2005).

Services can be defined broadly in two categories: personal-based services and knowledge-based services. Personal-based services often are thought of as services that require little specialized knowledge (e.g., serving in a restaurant, parking cars) in contrast to knowledge-based services that require a high degree of specialized knowledge (e.g., providing healthcare, designing skyscrapers). While differentiation between these two types of services initially may seem simple enough, determinations about which professions fall into either category can be imperfect (Vastine 2002). For example, it is unclear what delineates high from low degrees of specialized knowledge. Personal-based services are resistant to globalization, and, with a few exceptions, they also represent relatively low-paying jobs (Friedman 2005). Knowledge-based services are associated with relatively higher-paying jobs (e.g., education, consulting, engineering/design, and other applications of unique expertise) and are more susceptible to off-shoring (being geographically relocated). For example, architectural design is a knowledge-based service. Clients pay for building plans, but the actual plans may be drafted by architects in the same country as the clients or elsewhere in the world. In the globalized economy, local providers of services (such as architectural design) face competition from abroad similar to the competition faced by local providers of finished goods (Friedman 2005; OECD 2005).

Due to the increased competition generated by globalization, counselors have an increasingly diverse range of opportunities to apply their expertise and to help clients benefit from available knowledge-based services. The exchange of services and the resulting variety of options demands that counselors be increasingly savvy about how to offer their clients information (Hansen 2005; Sampson et al. 2000). Counselors must become familiar with which services and career avenues are available and how they are available in order to maintain their relevance as helpers.

\section{Practice Example}

Friedman (2005) described a situation that may seem familiar to many counselors. A family identifies the need for tutors for their children, but does not have the financial means to enroll their children in an after-school tutoring service and does not qualify for assistance programs. After some exploration, the family agrees to contract with a tutoring service in India that provides on-line tutoring at a fraction of the cost, which allows the family to obtain tutoring services for all of their children. This example highlights how globalization, manifested through the exchange of tutoring services, allowed a middle-income family in the USA to obtain tutoring services it would not have been able to afford otherwise. Situations such as the one described by Friedman evidence the need for counselors to encourage clients to broaden their view of available resources for meeting counseling goals.

\section{Exchange of People}


In the globalized world, people (or laborers in economist terms), migrate within and across national borders. The exchange of people is the global relocation of skilled and unskilled workers to wherever they are needed. This particular view of immigration has been identified as the neoclassical view by migration researchers (Massey 1999; Portes and Rumbaut 1990). The manifestation of globalization as the exchange of people may be its most tangible manifestation and may also have the most far-reaching consequences for the practice of counseling. In many cases, globalization is spurred when foreign labor is intentionally recruited. Examples of laborer recruitment include the Bracero program in the western USA of the 1940s and more recent examples such as the New Zealand government's skilled migrant categories (Immigration New Zealand 2005; Martinez 2002). Globalization also is spurred when workers migrate because of the perception that the opportunities for obtaining gainful employment would be better than in their countries of origin (Garcia 2004; Martinez 2002; Massey 1999; Portes and Rumbaut 1990). One dramatic illustration of this kind of migration is provided by the groups of individuals who sail for the Canary Islands and the European Union countries from Africa in the hopes of obtaining higher paying employment. In economic globalization terms, the movement of people from one country to another is the result of individuals and families adjusting to the opportunities in the global economy so that rewards for their work are maximized.

It also is important to recognize that although the emphasis heretofore has been on 'voluntary' migrants who come for economic reasons, counselors often work with involuntary migrants seeking asylum (Bemak et al. 2003; Fong 2004; Pumariega et al. 2005). Refugees are a part of many communities around the world (New Zealand Department of Labor, 2005; US Department of State, Bureau of Population, Refugees, and Migration 2006). Counselors in community agencies and schools work with refugee parents and families adjusting to disruption, dislocation, displacement of family and community, lack of accessibility to basic needs, violence, and life without the extended support systems they once had and depended upon (Asner-Self and Marotta 2005; Bean et al. 2001; Eisenbruch 1998; Jensen 1966; Marshall et al. 2005; Porter and Haslam 2006; Watters and Ingleby 2004). Often, school counselors may be new students' first contact with mental health expertise (ACA, American School Counselor Association, National Association of School Psychologists, School Social Work Association of America 2006; Baird 1997; Cornille et al. 1983; Porter et al. 2000). The process of facilitating the academic and social achievement of these students requires collaboration among many stakeholders, including counselors.

Practice Example

Charlotte, a primary school counselor, shares her time between two schools. Shortly before the first day of classes she is made aware of an incoming student who is a recent immigrant from East Africa. Over the past 5 years, her community has seen a dramatic increase in the number of East African immigrants as their community has been designated a refugee relocation center. School staff have found that reaching out to families has been helpful. When parents first came into register their daughter, the office staff had a difficult time with appropriate placement due to a lack of school records; there is some concern that she may have been placed at an inappropriate grade level. The school director has asked Charlotte to work with the student, the student's family, and various school personnel to help the student make a successful transition. 
This example demonstrates how globalization directly impacts the day-to-day work of professional counselors. A special case, forced migration, was used to model the point here, but in many communities around the world, counselors are attending to the needs of immigrants who more closely align with economists' views of migration. This example also hints at the impact that counselors can have on improving student and parent engagement in the school environment.

\section{Exchange of Knowledge}

The exchange of knowledge in the context of globalization, according to the IMF (2002) definition of globalization, is manifested by the exchange of technology. Similar to the exchange of goods and services, the exchange of technology need not be a tangible object like a mainframe computer. Technology can be manifest in processes such as those involved in manufacturing or refining goods or providing services (OECD 2005). Outcomes of technology exchange are more abstract because they do not necessarily render a new item, but probably improve upon a product or a way of doing something that already exists.

In the counseling context, knowledge exchange provides new avenues for professional development. Clearly, counseling is a process dependent upon a mutual understanding by the client and the counselor (Arredondo et al. 1996; Barrett-Lennard 1962, 1981; Rogers 1957, 1975; Sampson et al. 2000; Sue et al. 1992; Treviño 1996; Wrenn 1962). Counselors have an ethical responsibility to learn how to join with people from diverse backgrounds and to continuously expand their repertoire of techniques to help clients resolve their presenting problems. Knowledge exchange allows for technique development to take place internationally (Harper and Deen 2003; Sampson et al. 2000). Thus, counselors are responsible for remaining abreast of new findings related to effective counseling modalities.

In the counseling context, technology may refer to a technique, process, or theory. The counseling profession is rife with examples of technology exchange impacting practice. For example, the work of counselors in the USA has direct links to the technologies for understanding human behavior, development, and individual differences developed in Europe by Freud, Jung, Adler, Rank, Moreno, Piaget, and Binet, among others. More recently, the increasing participation of international students in counselor education programs has provided a mechanism for technology exchange to take place at the local level.

\section{Practice Example}

Colette, an international student, is working on a group presentation on depression for a counseling course. Like many international students at the graduate level, Colette is a fully vetted professional in her home country. She had several years of experience as a psychologist in her Central American homeland before going to Mexico to pursue a master's degree. Her colleagues in the presentation group are all from Mexico with varying degrees of professional experience. In developing a sample community-based intervention, Colette raises concerns about their plan to use a lecture-based psycheducational group. She had learned that skits or plays, rather than psycheducational lectures, were a more effective way of disseminating information in some of her homeland's communities. As a result, the group decides to develop a skit for their 
presentation and model how a facilitator might highlight certain events as indicators of depression.

As a result of Colette's experience, the group changed their strategy for a sample communitybased intervention. They saw how Colette's strategy could be adapted for a variety of languages and could reach clients with limited literacy levels. Following the group's presentation, fellow students shared their own ideas for community-based interventions. Ultimately, both Colette and her classmates were afforded the opportunity to infuse each other's technologies (i.e., skit-based and lecture-based interventions) into their skill sets.

\section{Globalization: Challenge to the Leadership}

Globalization is a phenomenon that counselors negotiate, as best they can, on a daily basis. Globalization also holds immeasurable opportunities and challenges to professional counseling, challenges that must be addressed by the profession's leadership in each country. Friedman (2005) labeled the current post-dot-com era of globalization as this generation's Sputnik. The launch of the Sputnik satellite in the late 1950s is particularly relevant to counseling as a profession and, subsequently the work of counseling practitioners in the USA and around the world. The policy changes that resulted from Sputnik greatly increased funding for the rapid development of counselor education programs and the placement of counselors in schools in the USA (Herr 2003; Sweeney 2001). Additionally, as funding became available for new industrial and technological sectors, the need for professionals in these fields grew worldwide. In the current climate of opportunities, professional organizations that define and represent the counseling profession, should assume their share of responsibility for assuring counselors are included in policy statements and that needed resources are available. Failure to attend to the role of the counselor both domestically and internationally in the context of globalization could lead to the marginalization of counselors. If counselors are unprepared to provide needed services at the confluence of clients' school, career/work, and mental health lives, other professionals will step in to meet those needs or will be assigned to do so by policymakers. In the USA, organizational efforts have been led by NBCC, CACREP, the Association for Counselor Education and Supervision (ACES), and ACA. A short summary of their activities, as an example of what counseling organizations in various settings might do in response to globalization, follows.

NBCC and CACREP are the quality assurance mechanisms that exist to support the credibility and quality of professional counselors and counselor education programs through certification and accreditation in the USA. Membership organizations such as ACA and ACES generally have more flexible criteria for inclusion in their registers and provide the mechanisms for scholarly exchange of information, ideas, and practices. The missions of both quality assurance and membership organizations complement each other, and are important to delineate.

\section{Quality Assurance: NBCC and CACREP}

NBCC has created NBCC International, an organization specifically designed to foster the growth of high quality counseling services through counselor credentialing and collaboration with colleagues in other parts of the world to define counseling in their own cultural and 
economic contexts. Similarly, CACREP has made public their plans to work with NBCC International and international colleagues to develop high quality counseling through accreditation (Bobby 2006; Culbreth 2006). The staffs at NBCC International and CACREP that are assigned to globalization issues have the specific aim of helping counselors to be recognized internationally as experts in career, school, and mental health services. In both the short-term and long-term, these groups' advocacy activities foster the development of quality assurance mechanisms abroad and help to bring counseling into the vernacular of consumers (clients) and international policy makers. With continued diligent work, it is reasonable to expect that economic and educational development projects include counselors who are experts in matching resources and opportunities with qualified individuals. Highlighting the skills of counselors promotes the profession by publicizing potential benefits they can offer other societies through provision of a variety of counseling services.

From the perspective of helping practicing counselors, international activities help collect the information needed to effectively practice counseling to mobile workers and families. Attention to globalization facilitates the exchange of technology necessary to provide competent crosscultural services. Setting quality-assurance standards is related to current practice. Therefore, bringing globalization issues into awareness helps assure standards reflect whatever needs counselors identify that result from globalization. Additionally, the exchange of career and educational system information such as what is required to become a counselor in a particular country provides counselors the information necessary to help make informed career choices. Similar work is being undertaken by the counselors exploring the European Accreditation Scheme (EAS) for careers guidance practitioners, a program that purports to facilitate full portability of counselor qualifications within the European Union (Reid 2007).

Membership Organizations

In addition to the quality assurance and promotion activities conducted by NBCC and CACREP, membership organizations in the USA, such as ACA and ACES, provide important avenues for counselors. Through their International Committee and International Counseling Interest Network, ACA and ACES have fostered the development of international relationships between their US memberships and those abroad. Through their scholarly activities (i.e., journals and conferences), membership organizations provide means for developing the counseling profession's unique body of knowledge. Journals, conferences, and interest network listservs become the means by which information is exchanged and globalization advances.

Examples of cooperation and collaboration between membership organizations and quality assurance groups include ACES' co-sponsorship of NBCC International Fellows events at the 2002 and 2005 ACES National Conferences. These events not only have helped to raise levels of knowledge and awareness about globalization issues among ACES members, but also have served to broaden ACES' reach through actively involving potential members from other countries. These kinds of connections foster opportunities to share ideas and practices, and increase awareness of needs. In addition, international fellows have been able to share ideas and realities about roles and challenges for professional counselors in serving client populations outside of the USA. This is particularly relevant as counselors from the USA increasingly respond to humanitarian disasters internationally. As the primary membership organization for 
counselor educators in the USA, ACES can work together with quality assurance organizations to support development of training for counselors and paraprofessionals who can provide needed services in other countries and other cultures. Finally, ACES can utilize members of its International Counseling and Multicultural interest networks to help in initiating and nurturing cross-cultural efforts.

In an open exchange of practices and ideas, counseling professionals, students, and educators from a variety of settings can broaden and deepen their understanding of the needs, realities, and challenges of providing human services to those in other countries and other cultures. Moreover, counselors can become aware of resources available from as well as needed by other countries which in turn can foster increased understanding of globalization issues. Finally, counselor education programs, suitably adjusted for cultural relevance, can open their doors wider to admit and train international students who can take what they learn back to their countries of origin to implement programs and services and, for some, to train others. Meanwhile, counselor education programs can benefit from the perspectives and resources these international students have to offer to local counseling students and counselor educators alike.

Quality assurance and membership organizations can collaborate to help the counseling profession better address the globalization-related demands placed upon counselors. Organizations are in a position to advocate for counselors to be included in long term economic and social development policies directed at responding to globalization. Counseling organizations also are in a position to facilitate the development of resources that have international relevance. One example of such an internationally relevant resource would be a single listing of all accredited tertiary education programs in the world.

The activities of organizations related to the USA have been briefly summarized in the hopes that reports from other national and international organizations will follow. Intentionality in assuming an international presence that is clearly responsive to globalization will help secure short- and long-term benefits for each of these organizations' constituents.

\section{Conclusions}

Globalization is a process that is likely to increasingly shape the economic and educational opportunities of subsequent generations. Although it is a long-standing phenomenon, advances in international investment, communication, and travel have made the benefits and challenges more palpable (Friedman 2005; OECD 2005; World Commission on the Social Dimension of Globalization 2004). The current period of globalization has been referred to as a challenge similar to the one provided by the Sputnik satellite launch, an event that spurred increased funding for counseling activities in the USA as well as international growth in research and technology. The counseling profession thrived as a consequence of Sputnik and its practitioners facilitated client achievement of career, school, and mental health goals. Counseling now finds itself at a similar crossroads where intentionality can lead to distinct benefits for clients and counselors or inactivity could lead to the irrelevance of the profession. Counselors currently are responding to the effects of globalization on their clients and their professional organizations should work actively to capitalize on the opportunities provided in the context of globalization. 
This article cannot address all of the complexities that characterize the experience of globalization's effects. One of the principal criticisms of globalization is that its social consequences have been unevenly distributed (Stiglitz 2006; World Commission on the Social Dimension of Globalization 2004). A comprehensive understanding of globalization's impact on all counselors and their clients will only be possible as counselors from other countries share their experiences. A clear understanding of how globalization is widely defined and why counselors should care about it provides an impetus for continued dialogue. Clearly, further research and advocacy extending beyond this primer are needed to assure the relevance of counselors and their interventions in an increasingly integrated world.

\section{References}

American Counseling Association (2005). Code of ethics. Alexandria, VA: American Counseling Association.

American Counseling Association, American School Counselor Association, National Association of School Psychologists, \& School Social Work Association of America. (2006). Removing barriers to learning and improving student outcomes: The importance of school-based mental health services. Retrieved December 11, 2006 from http://www.counseling.org/Files/FD.ashx?guid=4c99069e-f39a-4883-a8c3$5767356 \mathrm{c} 4312$.

Arredondo, P. (2006). Counseling/counselling around the world: Personal and professional perspectives. Counseling Today, 48(7), 5.

Arredondo, P., Toporek, R., Brown, S., Jones, J., Locke, D., Sanchez, J., et al. (1996).

Operationalization of the multicultural counseling competencies. Journal of Multicultural Counseling and Development, 24, 42-78.

Asner-Self, K. K., \& Marotta, S. A. (2005). Developmental indices among Central American immigrants exposed to war-related trauma: Clinical implications for counselors. Journal of Counseling and Development, 83, 162-171.

Baird, C. T. (1997). A systematic transition plan for new students. Professional School Counseling, 1, 69-70.

Barrett-Lennard, G. T. (1962). Dimensions of therapist response as causal factors in the therapeutic change. Psychological Monographs: General and Applied, 76(43), 1-36.

Barrett-Lennard, G. T. (1981). The empathy cycle: Refinement of a nuclear concept. Journal of Counseling Psychology, 28, 91-100.

Batalova, J., \& Lowell, B. L. (2006). 'The best and brightest': Immigrant professionals in the U.S. In M. P. Smith \& A. Favell (Eds.), The human face of global mobility (pp. 81-101). New Brunswick, NJ: Transaction Publishers.

Bean, R. A., Perry, B. J., \& Bedell, T. M. (2001). Developing culturally competent marriage and family therapists: Guidelines for working with Hispanic families. Journal of Marital and Family Therapy, 27, 43-53.

Bemak, F., Chung, R. C., \& Pedersen, P. B. (2003). Counseling refugees: A psychosocial approach to innovative multicultural interventions. Westport, CT: Greenwood.

Bennhold, K. (2007). France: Whither globalization. International Herald Tribune, April 2, 2007. Retrieved February 19, 2008 from http://www.iht.com/articles/2007/04/02/news/france.php. 
Bobby, C. L. (2006). The counseling profession: Meeting the needs of the never served. Paper presented at the meeting of the Center for Quality Assurance, San Jose, Costa Rica, June 2006.

Bradsher, K. (2006). Hong Kong arrests rile Koreans. New York Times, January 10, A12.

British Broadcasting Corporation (1999). Protests overshadow WTO talks. BBC News World Edition, November 30. Retrieved December 6, 2006 from http://news.bbc.co.uk/2/hi/americas/542622.stm.

Burawoy, M., Blum, J. A., George, S., Gille, Z., Gowan, T., Haney, L., et al. (2000). Global ethnography: Forces, connections, and imaginations in a postmodern world. Berkeley, CA: University of California Press.

Cheng, J. (2005). WTO puts Hong Kong on edge; how globalization foes are handled will carry high stakes. Wall Street Journal, September 1, A9.

Clawson, T. W., Szilagyi, A. A., Chao, H., Chen, M., Keller-Neethling, J. R., Korkut, F., et al. (2002). Spanning the globe-Counseling expands. Paper presented at the meeting of the Association for Counselor Education and Supervision, Park City, UT, October 2002.

Coe, D. T., Subramanian, A., Tamirisa, N. T., \& Bhavnani, R. (2002). The missing globalization puzzle. IMF Working Paper WP/02/171, International Monetary Fund, Washington, DC.

Collier, P., \& Dollar, D. (2002). Globalization, growth, and poverty. Washington, DC: Oxford University Press.

Collins-Dogrul, J. (2006). Managing US-Mexico “border health”: An organizational field approach. Social Science and Medicine, 63, 3199-3211.

Conley, T. (2002). The state of globalization and the globalization of the state. Australian Journal of International Affairs, 56, 447-471.

Cornille, T. A., Bayer, A. E., \& Smythe, C. K. (1983). Schools and newcomers: A national survey of innovative programs. Personnel and Guidance Journal, 62, 229-236.

Culbreth, J. (Interviewee) (2006). CACREP and the CACREP standards revision process with Dr. Jack Culbreth (audio program, March 9, 2006). Retrieved November 19, 2006 from http://www.counseloraudiosource.net/archives.htm.

Dobbs, L. (2004). Exporting America: Why corporate greed is shipping America's jobs overseas. New York: Warner Books.

Economic Commission for Latin America and the Caribbean (2002). Globalization and development. Brasilia: United Nations.

Eisenbruch, M. (1998). The mental health of refugee children and their cultural development. International Migration Review, 22, 282-300.

Evelyn, J. (2005). Community colleges go globe-trotting. The Chronicle of Higher Education, 51(23), A11 (11 February).

Federacion de Asociaciones Venezolanas de Orientadores (2001). Codigo de ética del profesional de la orientación. Guanare, Venezuela: Federacion de Asociaciones Venezolanas de Orientadores.

Fong, R. (2004). Culturally competent practice with immigrant and refugee children. New York: Guilford.

Friedman, T. L. (2005). The world is flat: A brief history of the 21st century (Rev. ed.). New York: Farrar, Strauss, \& Giraux.

Frist, W. (2003). Globalization and bioterrorism. Speech made on the floor of the U.S. Senate, June 11, 2003. Retrieved December 8, 2006 from 
http://frist.senate.gov/index.cfm?FuseAction=Speeches.Detail\&Speech_id=18\&Month=6 $\&$ Year $=2003$.

Garcia, A. M. (2004). Narratives of Mexican American women: Emergent identities of the second generation. Walnut Creek, CA: Altamira.

Gilbert, J. (2006). Cultural imperialism revisited: Counselling and globalization. International Journal of Critical Psychology, 17, 10-28.

Hansen, E. (2005). Career guidance: A resource handbook for low- and middle income countries. Geneva: International Labor Organization.

Harper, F. D., \& Deen, N. (2003). The international counseling movement. In F. D. Harper \& J. McFadden (Eds.), Culture and counseling: New approaches (pp. 147-163). Boston: Allyn \& Bacon.

Herr, E. L. (2003). Historical roots and future issues. In B. T. Erford (Ed.), Transforming the school counseling profession (pp. 21-38). Upper Saddle River, NJ: Merrill Prentice Hall.

Immigration New Zealand (2005). Immigration New Zealand. Retrieved February 19, 2008 from http://www.immigration.govt.nz/.

Institute of International Education (2005). Open doors report 2005. Washington, DC: Institute of International Education.

International Association for Educational and Vocational Guidance (1995). IAEVG ethical standards. Stockholm, Sweden: International Association for Educational and Vocational Guidance.

International Monetary Fund (2002). Globalization: Threat or opportunity? Retrieved March 16, 2006 from http://www.imf.org/external/np/exr/ib/2000/041200.htm.

Jensen, F. A. S. (1966). Psychological aspects of the social isolation of refugees. International Migration Review, 3, 40-60.

Kennedy, E. (2006). Senator Kennedy on globalization. Speech presented at Northeastern University, February 22, 2006. Retrieved December 8, 2006 from: http://www.tedkennedy.com/content/710/senator-kennedy-on-globalization.

Lenn, M., \& Reason, M. J. (2000). The globalization of the professions in the United States and Canada: A survey and analysis. Washington, DC: The Center for Quality Assurance in International Education.

Leong, F. T. L., \& Ponterotto, J. G. (2003). A proposal for internationalizing counseling psychology in the United States: Rationale, recommendations, and challenges. Counseling Psychologist, 31, 381-395.

Marshall, G. N., Schell, T. L., Elliott, M. N., Berthold, S., \& Chun, C. (2005). Mental health of Cambodian refugees two decades after resettlement in the United States. Journal of the American Medical Association, 294, 602-612.

Martin, S. F. (2001). Heavy traffic: International migration in an era of globalization. Brookings Review, Fall, 41-44.

Martinez, R. (2002). Crossing over: A Mexican family on the migrant trail. New York: Metropolitan Books.

Massey, D. S. (1999). Why does immigration occur? A theoretical synthesis. In C. Hirschman, P. Kasinitz, \& J. DeWind (Eds.), The handbook of international migration: The American Experience (pp. 34-52). New York: Russell Sage Foundation.

Massey University (2008). Welcome to Massey International. Retrieved February 19, 2008 from http://www.massey.ac.nz/massey/international/international_home.cfm. 
McMurtie, B. (2005). Special report: American universities step up their sales pitch. The Chronicle of Higher Education, 51(23), A8.

New Zealand Department of Labor (2005). Immigration trends 2004/2005. Wellington, NZ: Crown.

Oppenheimer, A. (2005). Cuentos chinos: El engaño de Washington, la mentira populista y la esperanza de America Latina. Buenos Aires: Editorial Sudamericana.

Organization for Economic Co-Operation and Development (2005). OECD handbook on economic globalization indicators. Paris: Organization for Economic Co-Operation and Development.

Polachek, S., Seiglie, C., \& Xiang, J. (2005). Globalization and international conflict: Can FDI increase peace? Rutgers University Newark Working Paper (\#2005-004).

Porter, G., Epp, L., \& Bryant, S. (2000). Collaboration among school mental health professionals: A necessity, not a luxury. Professional School Counseling, 3, 315-331.

Porter, M., \& Haslam, N. (2006). Predisplacement and postdisplacement factors associated with mental health of refugees and internally displaced persons: A meta-analysis. Journal of the American Medical Association, 294, 602-612.

Portes, A., \& Rumbaut, R. G. (1990). Immigrant America: A portrait. Berkeley, CA: University of California Press.

Pumariega, A. J., Rothe, E., \& Pumariega, J. B. (2005). Mental health of immigrants and refugees. Community Mental Health Journal, 41, 581-597.

Radipati, B. D. D. (2006). Is globalization passé? Socio-Economic Review, 4, 175-184.

Reid, H. L. (2007). Study on the accreditation schemes of OECD countries. Turin, Italy: European Accreditation Scheme for Careers Guidance Practitioners.

Rogers, C. R. (1957). The necessary and sufficient conditions of therapeutic personality change. Journal of Counseling Psychology, 21, 95-103.

Rogers, C. R. (1975). Empathic: An unappreciated way of being. The Counseling Psychologist, $5,2-9$.

Rollins, J. (Ed.) (2006). Getting a global perspective: A glimpse of the counseling profession in 27 countries. Counseling Today, 48(7), 34-43 (January).

Sampson, J. P., Jr., Watts, A. G., Palmer, M., \& Hughes, D. (2000). International collaboration in translating career theory to practice. Journal of Employment Counseling, 37, 98-106.

Schweiger, W. K. (2005). NBCC International. The National Certified Counselor, 21(2), 1 (Spring).

Singapore Association for Counseling (2004). Ethics. Retrieved 19 February 2008 from http://www.sac-counsel.org.sg/ethics.html.

Stead, G. B., \& Harrington, T. F. (2000). A process perspective of international research collaboration. Journal of Employment Counseling, 37, 88-96.

Stiglitz, J. E. (2006). Making globalization work. New York: W.W. Norton.

Suarez-Orozco, M. M. (2001). Globalization, immigration, and education: The research agenda. Harvard Educational Review, 71, 345-365.

Sue, D. W., Arredondo, P., \& McDavis, R. (1992). Multicultural counseling competencies and standards: A call to the profession. Journal of Counseling and Development, 70, 477485.

Sweeney, T. J. (2001). Counseling: historical origins and philosophical roots. In D. C. Locke, J. E. Myers, \& E. L. Herr (Eds.), The handbook of counseling (pp. 3-26). Thousand Oaks, CA: Sage. 
Treviño, J. G. (1996). Worldview: Change in cross-cultural counseling. The Counseling Psychologist, 24, 198-215.

US Department of State, Bureau of Population, Refugees, and Migration (2006). Proposed refugee admissions for fiscal year 2007: Report to the congress. Retrieved November 25, 2006, from http://www.state.gov/g/prm/rls/rpt/2006/73619.htm.

Vastine, R. (2002). Briefing on trade in education and training services: What is happening in the global trade talks and how this affects U.S. providers. In J. L. Deupree, M. E. Johnson, \& M. Lenn (Eds.), Higher education and training in the global marketplace: Exporting issues and the trade agreements. Washington, DC: CQAIE.

Watters, C., \& Ingleby, D. (2004). Locations of care: Meeting the mental health and social care needs of refugees in Europe. International Journal of Law and Psychiatry, 27, 549-570.

Winestock, F. (2001). For the WTO, no escape from protesters-At this trade summit, voices will be silenced, but issues still ring. Wall Street Journal, November 2, A12.

World Commission on the Social Dimension of Globalization (2004). A fair globalization: Creating opportunities for all. Geneva, Switzerland: International Labour Organization.

World Health Organization (2001). The World Health report 2001. Geneva: World Health Organization.

Wrenn, C. G. (1962). The culturally encapsulated counselor. Harvard Educational Review, 32, 444-449. 